\title{
Analisis Penggunaan Video sebagai Media Pembelajaran Terpadu terhadap Motivasi Belajar Siswa
}

\author{
Siska Maulani" ${ }^{* 1}$, Nisa Nuraisyah ${ }^{2}$, Dini Zarina ${ }^{3}$, Intan Velinda $^{4}$, Ani Nur Aeni ${ }^{5}$ \\ 1,2,3,4,5 Pendidikan Guru Sekolah Dasar Universitas Pendidikan Indonesia, Indonesia \\ Email: ${ }^{1}$ siskamaulani@upi.edu, ${ }^{2}$ ichanisaisyah@upi.edu, ${ }^{3}$ dinizarina@upi.edu, ${ }^{4}$ intanvelinda@upi.edu, \\ 5 aninuraeni@upi.edu
}

\begin{abstract}
Abstrak
Penelitian ini dilatarbelakangi oleh pentingnya keberadaan media pembelajaran berbasis teknologi berupa video pembelajaran. Adanya video pembelajaran ini sebagai upaya motivasi belajar siswa dimana dapat menciptakan suasana belajar yang menyenangkan dan siswa tidak merasa bosan selama pembelajaran berlangsung. Karena jarang sekali guru yang dalam kegiatan pembelajarannya menggunakan video. Adapun tujuan dari penelitian ini untuk mengetahui penggunaan video sebagai media pembelajaran terpadu terhadap motivasi belajar siswa. Metode penelitian yang digunakan adalah kualitatif deskriptif. Subjek penelitian adalah siswa kelas III SDN 1 Paniis yang berjumlah 26 orang. Instrumen yang digunakan adalah angket. Angket untuk mengukur motivasi belajar, respon siswa dan penyajian video dalam pembelajaran terpadu. Hasil penelitian menunjukkan bahwa : 1) Penggunaan video dalam pembelajaran terpadu memberikan kontribusi yang baik terhadap motivasi belajar siswa, dilihat dari frekuensi kategori sangat setuju sebesar $67,25 \%$,2) Siswa memberikan respon yang kurang baik terhadap pembelajaran terpadu menggunakan video pembelajaran, dilihat dari frekuensi kategori sangat setuju sebesar $43,5 \%, 3$ ) Penyajian video dalam pembelajaran terpadu telah disajikan dengan baik, dilihat dari frekuensi kategori sangat setuju sebesar $63 \%$.
\end{abstract}

Kata kunci: Media, Motivasi Belajar, Pembelajaran Terpadu, Video Pembelajaran

\section{Judul Bahasa Inggris}

\begin{abstract}
This research is motivated by the importance of the existence of technology-based learning media in the form of learning videos. The existence of this learning video is an effort to motivate students to learn which can create a fun learning atmosphere and students do not feel bored during the learning process. Because it is rare for teachers to use video in their learning activities. The purpose of this study was to determine the use of video as an integrated learning media on students' learning motivation. The research method used is descriptive qualitative. The research subjects were the third grade students of SDN 1 Paniis, totaling 26 people. The instrument used is a questionnaire. Questionnaire to measure learning motivation, student response and video presentation in integrated learning. The results showed that: 1) The use of video in integrated learning gave a good contribution to students' learning motivation, seen from the frequency of the category strongly agreed at $67.25 \%$, 2) Students gave a not so good response to integrated learning using learning videos, seen from the frequency the category strongly agrees at 43,5\%,3) The presentation of videos in integrated learning has been presented well, seen from the frequency of the category strongly agrees at $63 \%$.
\end{abstract}

Keywords: Integrated learning, learning motivation, learning videos, Media

\section{PENDAHULUAN}

Perkembangan teknologi saat ini berlangsung pesat dan berpengaruh pada berbagai aspek kehidupan. Salah satu aspek kehidupan yang tidak terlepas dari perkembangan teknologi adalah pendidikan. Adanya perkembangan teknologi ini menuntut para guru tidak hanya professional, namun harus mengimbangi dan memanfaatkan perkembangan teknologi dalam proses pembelajaran. Guru harus mampu merubah cara mendidik yang relevan dengan perkembangan zaman. Diantaranya dengan menggunakan media pembelajaran yang inovatif berbasis teknologi agar kegiatan pembelajaran menjadi lebih menarik dan menyenangkan bagi siswa. Salah satu jenis media pembelajaran yang dapat digunakan oleh guru yaitu media audio dan visual berupa video. Video dapat menggambarkan suatu proses secara tepat dan dapat dilihat secara berulang-ulang, video juga 
mendorong dan meningkatkan motivasi siswa untuk tetap melihatnya [1]. Dalam kegiatan belajar mengajar peranan motivasi sangat diperlukan, sehingga penting bagi seorang guru untuk terus memotivasi peserta didiknya dengan memfasilitasi media pembelajaran yang menarik dan inovatif.

Keberadaan media dalam pembelajaran merupakan hal yang penting karena sebagai alat bantu untuk memudahkan guru dalam penyampaian pesan- pesan materi pelajaran kepada siswa. Guru sadar bahwa tanpa bantuan media pembelajaran siswa akan sulit untuk memahami materi pelajaran terutama materi pelajaran yang sangat komplek dan rumit. Sejalan dengan hal tersebut media pembelajaran bertujuan untuk meminimalisir penyampaian materi pembelajaran, membantu siswa memahami materi pembelajaran, sehingga menjadi lebih mudah dan efisien serta tercapainya pembelajaran yang efektif [2].

Selain karena perkembangan teknologi yang pesat, sistem pembelajaran yang dilakukan secara daring atau online di masa pandemi juga menuntut guru untuk kreatif dan optimal dalam melaksanakan kegiatan pembelajaran. Pembelajaran daring sangat berpengaruh terhadap motivasi belajar siswa karena proses belajar yang berbeda. Siswa cenderung kurang aktif dalam mengikuti pembelajaran Ada kemungkian besar siswa menjadi malas mengikuti pembelajaran daring. Tidak adanya motivasi siswa dalam pembelajaran daring dikarenakan kurangnya bersosialisasi dengan lingkungan dan teman sebaya, sehingga menyebabkan menurunnya motivasi belajar siswa pada saat mengikuti pembelajaran. Siswa juga sering mengalami kebosanan dikarenakan hanya bertemu dengan teman-teman dan gurunya melalui media virtual yang biasanya hanya menggunakan WhatsApp, tidak bertemu secara langsung. Untuk menunjang pembelajaran yang optimal dan lebih bermakna bagi siswa, dibutuhkan media yang cocok digunakan secara daring yaitu berupa video pembelajaran. Media video pembelajaran dianggap tepat digunakan saat pandemi karena mudah digunakan dan dapat diikuti oleh seluruh siswa [3]. Video pembelajaran dapat diputar dan dipelajari siswa dimanapun dan kapanpun. Dengan kata lain adanya video mampu mengatasi keterbatasan jarak dan waktu di masa pembelajaran jarak jauh atau daring seperti sekarang. Seperti dalam penelitian terdahulu yang membahas tentang pengembangan video pembelajaran untuk meningkatkan motivasi dan hasil belajar kognitif siswa kelas IV SD. Metode penelitian yang digunakan dalam penelitian ini adalah Quasi eksperimen. Hasil penelitian menunjukkan bahwa media video pembelajaran layak digunakan menurut ahli materi dan ahli media dengan kategori "baik". Produk yang dikembangkan juga terbukti efektif meningkatkan motivasi dan hasil belajar kognitif siswa kelas IV SD Gugus Pacarejo. Rata-rata skor motivasi dan nilai hasil belajar kognitif pada kelas eksperimen lebih tinggi daripada kelas control [4].

Berdasarkan uraian diatas, peneliti tertarik untuk melakukan penelitian dengan judul "Analisis Penggunaan Video Sebagai Media Pembelajaran Terpadu terhadap Motivasi Belajar Siswa”. Adapun rumusan masalah dari penelitian ini adalah sebagai berikut: 1) Bagaimana motivasi belajar siswa setelah pembelajaran terpadu melalui video?, 2) Bagaimana respon siswa terhadap pembelajaran terpadu melalui video?, 3) Bagaimana penyajian video dalam pembelajaran terpadu?

Berdasarkan rumusan masalah diatas, bahwa tujuan dari penelitian ini adalah untuk mengetahui: 1) Motivasi belajar siswa setelah pembelajaran terpadu melalui video, 2) Respon siswa terhadap pembelajaran terpadu melalui video. 3) Penyajian video dalam pembelajaran terpadu

\section{METODE PENELITIAN}

Penelitian ini menggunakan penelitian kualitatif yang dilakukan untuk menggali, memahami, dan menggambarkan suatu obyek penelitian dengan cara deskriptif berupa kata-kata dan bahasa [5]. Teknik pengumpulan data penelitian ini menggunakan angket atau kuisioner yang disebarkan kepada siswa kelas 3 SDN 1 Paniis. Angket tersebut berupa seperangkat pertanyaan tertulis yang disampaikan kepada responden untuk diisi olehnya tanpa intervensi dari peneliti.

Lokasi penelitian adalah di SD Negeri 1 Paniis yang berlokasi di Desa Paniis Kecamatan Pasawahan Kabupaten Kuningan Provinsi Jawa Barat. Sumber datanya adalah siswa kelas 3 sebanyak 26 siswa. Sumber data dalam penelitian ini yaitu hasil dari kuisioner. Peneliti melakukan analisis data melalui tahapan reduksi data, penyajian data, dan penarikan kesimpulan [6].

Intrumen penelitian yang digunakan adalah angket dimana pada penelitian ini berisi butir pernyataan yang ditujukan kepada siswa saat pembelajaran berlangsung. Angket digunakan untuk mengetahui motivasi belajar siswa dengan penggunaan video pembelajaran sebagai media pembelajaran terpadu terhadap motivasi belajar siswa.

Metode pengolahan data menjelaskan prosedur pengolahan dan analisis data sesuai dengan pendekatan yang dilakukan. Karena penelitian ini menggunakan metode kualitatif, maka metode pengolahan data dilakukan dengan menguraikan data dalam bentuk kalimat teratur, runtun, logis, tidak tumpang tindih, dan efektif sehingga memudahkan pemahaman dan interpretasi data. Diantaranya melalui tahap: pemeriksaan data (editing), klasifikasi (classifying), verifikasi (verifying), analisis (analysing), dan pembuatan kesimpulan (concluding). 
Sebelum dilakukan kegiatan pengumpulan data yang sebenarnya, terlebih dahulu dilakukan uji coba terhadap angket kepada subjek yang mempunyai sifa-tsifat yang sama dengan sampel penelitian. Pengujian instrumen dilakukan bertujuan untuk mengetahui tingkat kesahihan dan keandalan instrumen tersebut untuk mengambil data yang dibutuhkan. Pengujian instrumen dalam penelitian ini dilakukan dengan uji validitas

Sebelum dilakukan kegiatan pengumpulan data yang sebenarnya, terlebih dahulu dilakukan uji coba terhadap angket kepada subjek yang mempunyai sifa-tsifat yang sama dengan sampel penelitian. Pengujian instrumen dilakukan bertujuan untuk mengetahui tingkat kesahihan dan keandalan instrumen tersebut untuk mengambil data yang dibutuhkan. Pengujian instrumen dalam penelitian ini dilakukan dengan uji validitas instrumen dan uji reliabilitas instrumen. Uji coba instrumen dilakukan agar mendapatkan instrumen yang memiliki validitas dan reliabilitas sesuai dengan ketentuan, sehingga dapat digunakan untuk menjaring data yang dibutuhkan dalam menjawab permasalahan yang telah dirumuskan

\section{HASIL DAN PEMBAHASAN}

\subsection{Motivasi Belajar Siswa Setelah Pembelajaran Terpadu melalui Video}

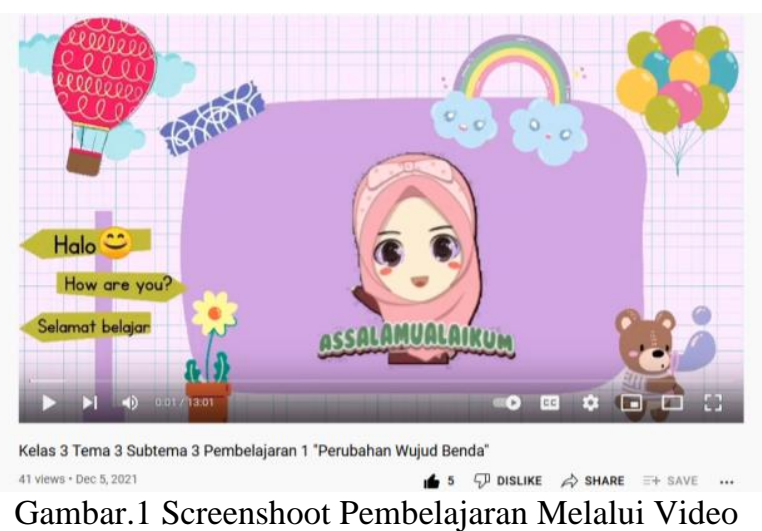

Data mengenai hal ini diperoleh dari hasil angket yang telah diisi oleh 26 responden. Berikut hasil pengolahan data mengenai hal ini

Tabel 1. Hasil Pengolahan Data Rumusan Masalah No. 1

\begin{tabular}{|c|c|c|c|c|c|c|c|c|}
\hline \multirow{2}{*}{ Pernyataan } & \multicolumn{2}{|c|}{ SS } & \multicolumn{2}{|c|}{$S$} & \multicolumn{2}{|c|}{$\mathrm{TS}$} & \multicolumn{2}{|c|}{ STS } \\
\hline & Jumlah & $\%$ & Jumlah & $\%$ & Jumlah & $\%$ & Jumlah & $\%$ \\
\hline $\begin{array}{c}\text { Saya antusias mengikuti } \\
\text { pembelajaran yang disajikan dalam } \\
\text { bentuk video }\end{array}$ & 17 & 65 & 9 & 35 & & & & \\
\hline $\begin{array}{c}\text { Belajar menggunakan video } \\
\text { pembelajaran sangat menyenangkan }\end{array}$ & 19 & 73 & 6 & 23 & 1 & 4 & & \\
\hline $\begin{array}{c}\text { Saya merasa lebih mudah memahami } \\
\text { materi pembelajaran menggunakan } \\
\text { video }\end{array}$ & 13 & 50 & 12 & 46 & 1 & 4 & & \\
\hline $\begin{array}{c}\text { Saya mengamati video pembelajaran } \\
\text { dari awal sampai akhir }\end{array}$ & 21 & 81 & 3 & 11 & 1 & 4 & 1 & 4 \\
\hline Jumlah & 70 & 269 & 30 & 115 & 3 & 12 & 1 & 4 \\
\hline Rata-rata & 17,5 & 67,25 & 7,5 & 28,75 & 0,75 & 3 & 0,25 & 1 \\
\hline Interpretasi kategori sangat setuju & & & & & & & & \\
\hline
\end{tabular}

1. Tanggapan responden terhadap pernyataan no. 1 yaitu "Saya antusias mengikuti pembelajaran yang disajikan dalam bentuk video" dari total 26 responden, $65 \%$ responden memilih sangat setuju, dan $35 \%$ responden memilih setuju. Berarti sebagian besar responden memilih sangat setuju. Kondisi ini termasuk ke dalam kategori baik. Artinya Sebagian besar siswa antusias dalam mengikuti pembelajaran terpadu yang disajikan dalam bentuk video. 
2. Tanggapan responden terhadap pernyataan no. 2 yaitu "Belajar menggunakan video pembelajaran sangat menyenangkan", $73 \%$ responden memilih sangat setuju, $23 \%$ responden memilih setuju, dan $4 \%$ responden memilih tidak setuju. Berarti sebagian besar responden memilih sangat setuju. Kondisi ini termasuk ke dalam kategori baik. Artinya dari pemerolehan data tersebut, siswa merasa senang ketika belajar menggunakan video pembelajaran.

3. Tanggapan responden terhadap pernyataan no. 3 yaitu "Saya merasa lebih mudah memahami materi pembelajaran menggunakan video", $50 \%$ responden memilih sangat setuju, $46 \%$ responden memilih setuju, dan $4 \%$ responden memilih tidak setuju. Berarti setengahnya responden memilih sangat setuju. Kondisi ini termasuk ke dalam kategori cukup baik. Artinya setengahnya siswa merasa lebih mudah memahami materi pembelajaran yang disajikan dalam bentuk video.

4. Tanggapan responden terhadap pernyataan no. 4 yaitu "Saya mengamati video pembelajaran dari awal sampai akhir", $81 \%$ responden memilih sangat setuju, $11 \%$ responden memilih setuju, $4 \%$ responden memilih tidak setuju, dan $4 \%$ responden memilih sangat tidak setuju. Berarti hampir seluruhnya responden yang memilih sangat setuju. Kondisi ini termasuk ke dalam kategori baik sekali. Artinya hampir seluruhnya siswa memiliki motivasi belajar yang baik yaitu ditunjukkan dengan mengamati video pembelajaran dari awal sampai akhir.

Berdasarkan data yang diperoleh, penggunaan video pembelajaran memberikan kontribusi yang baik dalam meningkatkan motivasi belajar siswa. Hal ini ditunjukkan dari antusias siswa dalam mengikuti pembelajaran, rasa senang siswa ketika belajar dengan disajikan video pembelajaran, daya tangkap siswa dalam memahami materi pembelajaran dengan lebih mudah, dan siswa dapat mengikuti serta mengamati video pembelajaran tersebut dari awal sampai akhir. Motivasi merupakan salah satu faktor yang menentukan keberhasilan dalam proses belajar, karena tanpa adanya motivasi maka kecil kemungkinan seorang siswa dapat berhasil dalam belajar. Motivasi belajar yang baik akan berdampak pada prestasi yang tinggi [7]. Sebaliknya, apabila siswa tidak memiliki motivasi belajar yang baik, maka akan berdampak pada prestasi yang belum sesuai dengan harapan.

Berdasarkan data sebelumnya nampak bahwa sebagian besar siswa sangat antusias dalam mengikuti pembelajaran yang disajikan dalam bentuk video. Rasa antusias ini menjadi motivasi yang luar biasa dalam mencapai suatu tujuan pembelajaran. Video pembelajaran ini dapat menarik perhatian siswa untuk belajar sehingga muncul rasa antusias siswa dalam mengikuti pembelajaran. Fungsi atensi media pembelajaran adalah bahwa media video dapat menarik perhatian dan mengarahkan konsentrasi audiens dalam hal ini yaitu siswa pada materi yang disajikan dalam bentuk video [8].

Motivasi belajar siswa muncul ketika siswa dapat merasa senang dengan apa yang ia pelajarinya. Digunakannya sebuah media video dalam pembelajaran dapat menciptakan suasana belajar yang menyenangkan bagi siswa. Motivasi belajar memegang peranan penting dalam memberikan gairah, semangat dan rasa senang dalam belajar sehingga siswa yang mempunyai motivasi tinggi mempunyai energi yang banyak untuk melaksanakan kegiatan belajar mengajar. Siswa yang mempunyai motivasi tinggi sangat sedikit kesalahan dalam belajarnya [9].

Berdasarkan data sebelumnya nampak bahwa setengahnya siswa merasa lebih mudah memahami materi pembelajaran yang disajikan dalam bentuk video. Pada dasarnya penggunaan media dalam pembelajaran mempunyai manfaat untuk memudahkan siswa dalam memahami materi pembelajaran yang akan disampaikan oleh guru. Media dapat membuat siswa lebih tertarik dan semangat dalam mengikuti proses pembelajaran, sehingga siswa dapat memahami konsep materi lebih mudah [10]. Pemanfaatan teknologi sebagai media mampu meningkatkan penguasaan konsep siswa, sehingga pesan yang disampaikan pendidik melalui media yang memanfaatkan media akan mudah ditangkap siswa [10].

Berdasarkan data sebelumnya nampak bahwa hampir seluruhnya siswa mulai muncul motivasi belajar yang baik sekali dengan ditunjukkannya sikap siswa dalam belajar yaitu dengan mengamati video pembelajaran dari awal sampai akhir. Dapat dikatakan bahwa penggunaan video pembelajaran tersebut dapat menarik perhatian siswa untuk belajar. Penyajian materi menggunakan video yang langsung dijelaskan oleh guru menggunakan suara/audio tersebut lebih disukai siswa dan membuat siswa sangat antusias karena dapat melihat peristiwa sebenarnya melalui video atau gambar yang ditayangkan [11].

\subsection{Respon Siswa Terhadap Pembelajaran Terpadu Melalui Video}

Data Mengenai hal ini diperoleh dari hasil angket yang telah diisi oleh 26 responden. Berikut hasil pengolahan data mengenai hal ini.

1. Tanggapan responden terhadap pernyataan no. 5 yaitu "Saya mengemukakan hasil pengamatan video pembelajaran" dari total 26 responden, $46 \%$ responden memilih sangat setuju, dan 50\% responden memilih setuju, dan $4 \%$ responden memilih sangat tidak setuju. Berarti setengahnya responden memilih setuju. 
Kondisi ini termasuk ke dalam kategori cukup baik. Artinya setengahnya siswa memiliki respon yang cukup baik dalam mengemukakan hasil pengamatan video pembelajaran.

2. Tanggapan responden terhadap pernyataan no. 6 yaitu "Saya aktif bertanya dan mengungkapkan pendapat", $70 \%$ responden memilih sangat setuju, $27 \%$ responden memilih setuju, dan $4 \%$ responden memilih tidak setuju. Berarti sebagian besar responden memilih sangat setuju. Kondisi ini termasuk ke dalam kategori baik. Artinya dari pemerolehan data tersebut, respon siswa yang ditunjukkan terhadap keterlibatan siswa aktif bertanya dan mengungkapkan pendapat terlihat baik.

3. Tanggapan responden terhadap pernyataan no. 7 yaitu "Saya tidak menjawab pertanyaan yang diajukan oleh guru saat pembelajaran", 20\% responden memilih sangat setuju, 12\% responden memilih setuju, 58\% responden memilih tidak setuju, dan $8 \%$ responden memilih sangat tidak setuju. Berarti Sebagian besar responden memilih tidak setuju. Kondisi ini termasuk ke dalam kategori baik. Artinya sebagian besar siswa dapat menjawab pertanyaan yang diajukan oleh guru saat pembelajaran.

4. Tanggapan responden terhadap pernyataan no. 8 yaitu "Saya menyimpulkan ringkasan materi pembelajaran", 38\% responden memilih sangat setuju, 54\% responden memilih setuju, dan $8 \%$ responden memilih sangat tidak setuju. Berarti sebagian besar responden yang memilih setuju. Kondisi ini termasuk ke dalam kategori baik. Artinya sebagian besar siswa menyimpulkan ringkasan materi pembelajaran tetapi kebiasaan itu tidak konsisten karena dapat dilihat dari pilihan siswa dalam menjawab angket.

Tabel 2. Hasil Pengolahan Data Rumusan Masalah No. 2

\begin{tabular}{|c|c|c|c|c|c|c|c|c|}
\hline \multirow{2}{*}{ Pernyataan } & \multicolumn{2}{|c|}{ SS } & \multicolumn{2}{|c|}{$\mathrm{S}$} & \multicolumn{2}{|c|}{ TS } & \multicolumn{2}{|c|}{ STS } \\
\hline & Jumlah & $\%$ & Jumlah & $\%$ & Jumlah & $\%$ & Jumlah & $\%$ \\
\hline $\begin{array}{c}\text { Saya mengemukakan hasil } \\
\text { pengamatan video } \\
\text { pembelajaran }\end{array}$ & 12 & 46 & 13 & 50 & & & 1 & 4 \\
\hline $\begin{array}{c}\text { Saya aktif bertanya dan } \\
\text { mengungkapkan pendapat }\end{array}$ & 18 & 70 & 7 & 27 & 1 & 4 & & \\
\hline $\begin{array}{c}\text { Saya tidak menjawab } \\
\text { pertanyaan yang diajukan } \\
\text { oleh guru saat pembelajaran }\end{array}$ & 5 & 20 & 3 & 12 & 15 & 58 & 2 & 8 \\
\hline $\begin{array}{l}\text { Saya menyimpulkan } \\
\text { ringkasan materi } \\
\text { pembelajaran }\end{array}$ & 10 & 38 & 14 & 54 & & & 2 & 8 \\
\hline Jumlah & 45 & 174 & 37 & 143 & 16 & 62 & 5 & 20 \\
\hline Rata-rata & 11,25 & 43,5 & 9,25 & 35,75 & 4 & 15,5 & 1,25 & 5 \\
\hline $\begin{array}{c}\text { Interpretasi kategori sangat } \\
\text { setuju }\end{array}$ & Kura & Baik & & & & & & \\
\hline
\end{tabular}

Pembelajaran dapat dikemas dalam berbagai media pembelajaran, salah satunya yaitu video pembelajaran. Media ini menyajikan berbagai materi pembelajaran yang akan disampaikan oleh guru kepada siswa. Siswa menjadi lebih mengerti tentang berbagai pekerjaan yang ada di sekitar dengan melihat video pembelajaran, sebab di dalam video tersebut memaparkan kejadian nyata dengan jelas yang dapat di lihat dan di dengar langsung oleh siswa [12]. Siswa mampu menjelaskan dengan hanya mengamati video karena dapat terlihat jelas bagaimana proses pekerjaan tersebut berlangsung, tetapi tetap dengan pemberian informasi dari guru agar siswa lebih jelas lagi dalam memahami materi tersebut.

Video pembelajaran menciptakan respon siswa yang beragam karena sebagai seorang pendidik harus mengetahui bagaimana respon siswa terhadap kegiatan belajar mengajar dan respon juga bisa berfungsi sebagai penentu kelemahan dan kelebihan dari suatu media terutama media video pembelajaran tersebut, karna bisa berfungsi sebagai evaluasi dari kegiatan belajar mengajar yang dilakukan, sehingga pendidik bisa membenahi kekuarangan atau apa yang dibutuhkan dari pembelajaran

Pembelajaran yang menarik membuat siswa lebih senang dan mudah menyerap ilmu yang terlihat dari respon siswa selama proses pembelajaran [13]. Respon siswa merupakan reaksi sosial yang dilakukan siswa dalam menanggapi pengaruh atau rangsangan dari situasi yang dilakukan orang lain. Respon sendiri memliki arti sebagai tanggapan berupa positif dan negatif dari sesuatu yang disajikan atau ditampilkan sehingga dapat dilakukan refleksi. Penelitian terdahulu yang berjudul "Respon Siswa Terhadap Penggunaan Video Youtube Sebagai Media Pembelajaran Daring Matematika" dengan didapatkan hasil 82\% respon siswa aterhadap video pembelajaran youtube sebagai media pembelajaran matermatika sangat baik [14]. Respon siswa ini bisa menjadi bahan pertimbangan kepada guru bagaimana sebaiknya video pembelajaran itu dibuat dengan melihat apa saja 
kekurangan yang dirasa perlu untuk diubah atau ditambah. Sehingga video pembelajaran dapat diaplikasikan dengan baik dan mendapatkan respon siswa yang positif kemudian materi pembelajaran yang terkandung dalam video tersebut dapat tersampaikan dengan baik pula

\subsection{Penyajian Video Pembelajaran dalam Pembelajaran Terpadu}

Data Mengenai hal ini diperoleh dari hasil angket yang telah diisi oleh 26 responden. Berikut hasil pengolahan data mengenai hal ini.

Tabel 3. Hasil Pengolahan Data Rumusan Masalah No. 3

\begin{tabular}{|c|c|c|c|c|c|c|c|c|}
\hline \multirow{2}{*}{ Pernyataan } & \multicolumn{2}{|c|}{ SS } & \multicolumn{2}{|c|}{$\mathrm{S}$} & \multicolumn{2}{|c|}{ TS } & \multicolumn{2}{|c|}{ STS } \\
\hline & Jumlah & $\%$ & Jumlah & $\%$ & Jumlah & $\%$ & Jumlah & $\%$ \\
\hline $\begin{array}{c}\text { Suara yang terdapat dalam } \\
\text { video sangat jelas }\end{array}$ & 15 & 58 & 9 & 35 & 2 & 8 & & \\
\hline $\begin{array}{c}\text { Tampilan dalam video sangat } \\
\text { menarik }\end{array}$ & 20 & 77 & 4 & 15 & 2 & 8 & & \\
\hline $\begin{array}{l}\text { Isi materi yang terdapat dalam } \\
\text { video sangat jelas }\end{array}$ & 14 & 54 & 11 & 42 & & & 1 & 4 \\
\hline Jumlah & 49 & 189 & 24 & 91 & 4 & 16 & 1 & 4 \\
\hline Rata-rata & 16,33 & 63 & 8 & 30,33 & 1,33 & 5,33 & 0,33 & 1,33 \\
\hline $\begin{array}{l}\text { Interpretasi kategori sangat } \\
\text { setuju }\end{array}$ & \multicolumn{2}{|c|}{ Baik } & & & & & & \\
\hline
\end{tabular}

1. Tanggapan responden terhadap pernyataan no. 9 yaitu "Suara yang terdapat dalam video sangat jelas" dari total 26 responden, 58\% responden memilih sangat setuju, dan 35\% responden memilih setuju dan $8 \%$ responden memilih tidak setuju. Berarti sebagian besar responden memilih sangat setuju. Kondisi ini termasuk ke dalam kategori baik. Artinya Sebagian besar siswa setuju bahwa suara dalam video sangat jelas.

2. Tanggapan responden terhadap pernyataan no. 10 yaitu "Tampilan dalam video sangat menarik", 77\% responden memilih sangat setuju, 15\% responden memilih setuju, dan $8 \%$ responden memilih tidak setuju. Berarti sebagian besar responden memilih sangat setuju. Kondisi ini termasuk ke dalam kategori baik. Artinya dari pemerolehan data tersebut, Sebagian besar siswa merasa tampilan dalam video sangat menarik.

3. Tanggapan responden terhadap pernyataan no. 11 yaitu "Isi materi yang terdapat dalam video sangat jelas", $54 \%$ responden memilih sangat setuju, $42 \%$ responden memilih setuju, dan $4 \%$ responden memilih sangat tidak setuju. Berarti setengahnya responden memilih sangat setuju. Kondisi ini termasuk ke dalam kategori cukup baik. Artinya setengahnya siswa merasa bahwa isi materi dalam video sangat jelas.

Video pembelajaran merupakan sumber daya yang kaya dan juga dinilai hidup bagi aplikasi multimedia. Video juga merupakan penyajian gambar yang bergerak, jika objek pada sebuah animasi adalah buatan maka objek pada video ini adalah nyata [15]. Pesan atau isi materi yang disampaikan dalam video pembelajaran dapat dinilai efektif, hal ini berdasarkan bahwa video pembelajaran dapat mempermudah siswa menangkap atau memperoleh pesan dalam video pembelajaran tersebut dengan mudah. Dalam Penyajiannya, video pembelajaran tersebut merupakan pengembangan dari isi materi-materi yang akan disampaikan, banyak sekali aplikasi yang dapat digunakan untuk membuat video pembelajaran tersebut, dengan aplikasi yang beragam juga lah yang bisa membuat video pembelajaran tersebut dapat dikembangkan lagi dalam penyajiannya. Maka dari itu guru harus Menyusun kerangka video pembelajaran dan dipersiapakan dengan baik.

Langkah-langkah umum yang paling utama pada pendekatan saintifik, adalah kegiatan mengamati. Kegiatan belajar pada kegiatan mengamati meliputi membaca, mendengar dan melihat. Media video pembelajaran ini memadukan antara mendengar dan melihat, sehingga media ini sangat bagus dan sesuai jika diterapkan pada kurrikulum 2013 [12]. Dalam media pembelajaran berupa video yang menyajikan visual dan audio dapat menambah antusias siswa dalam pembelajaran. Namun hal ini juga harus diperhatikan dimana penyajian video pembelajaran harus sesuai dengan kebutuhan peserta didik sesuai dengan jenjang pendidikan, guru juga sebaiknya amelihat terlebih dahulu konten apa yang sesuai dengan usia peserta didik.

Penyajian Video Pembelajaran tidak bisa dibuat begitu saja melainkan harus ada rancangan atau Langkahlangkah untuk membuat video yang menarik. Berikut langkah praktis menyusun naskah video pembelajaran adalah: (a) lihat indikator atau materi yang akan disajikan, pilih format sajian sesuai karakteristik materi yang akan disajikan,(b) bumper tune, penanda singkat sebuah program acara, (d) teaser (pembuka) cuplikan gambar yang akan dibahas, (e) isi bagian visual dengan perintah deskripsi, (f) utamakan visual gerak, berwarna, tiga dimensi dan detail, (g) sesuai narasi, (h) penulisan caption sesuai EYD, singkat dan tidak lebih lima baris, (i) 
sajikan materi yang menarik, jelas, mudah diingat, (j) pengulangan tidak sama persis dengan sajian materi, (k) latihan dibuat dalam bentuk soal tertutup sebagai bentuk penguat sajian materi, (l) audio sebagai penguat atau penjelasan visual yang belum jelas, (m) narasi tidak menggurui, disesuaikan dengan situasi dan kondisi [16].

Pada penyajiannya video pembelajaran ini harus dibuat secara interaktif, jangan sampai hanya pemaparan video pembelajarannya saja dan siswa hanya diberi kesempatan untuk menonton tanpa ada interaksi dari guru dan siswa. Adanya pengembangan media pembelajaran berbasis vidio tutorial interaktif diharapkan dapat memenuhi kebutuhan siswa [17]. Dengan kemasan dan penyajian yang menarik, dapat memunculkan semangat belajar, menarik minat, membantu siswa lebih memahami dan menguasai materi pelajaran dan meningkatkan hasil belajar. Media pembelajaran dapat digunakan langsung dalam proses belajar mengajar di kelas atau laboratorium dan dapat digunakan siswa sebagai pembelajaran secara mandiri

\section{KESIMPULAN}

Berdasarkan hasil penelitian yang telah dilaksanakan, maka diperoleh beberapa kesimpulan sebagai berikut: 1. Penggunaan video dalam pembelajaran terpadu memberikan kontribusi yang baik terhadap motivasi belajar siswa, dilihat dari frekuensi kategori sangat setuju sebesar 67,25\%. 2. Siswa memberikan respon yang kurang baik terhadap pembelajaran terpadu menggunakan video pembelajaran, dilihat dari frekuensi kategori sangat setuju sebesar 43,5\%, 3. Penyajian video dalam pembelajaran terpadu telah disajikan dengan baik, dilihat dari frekuensi kategori sangat setuju sebesar $63 \%$.

\section{DAFTAR PUSTAKA}

[1] A. Arsyad, Media Pembelajaran. Jakarta: PT Raja Grafindo Persada, 2011.

[2] N. Sudjana, and R. Ahmad, Media Pengajaran. Bandung: PT Sinar Batu Algesino. 2010.

[3] Y. Alami, "Media Pembelajaran daring pada Masa Covid-19," Tarbiyatu waTa'lim: Jurnal Pendidikan Agama Islam, vol. 2, no. 1, pp. 49-50, 2020.

[4] T. Suryansyah, and Suwarjo. Pengembangan Video Pembelajaran Untuk Meningkatkan Motivasi dan Hasil Belajar Kognitif Siswa Kelas IV SD. Jurnal Prima Edukasia. Volume 4-No 2 pp. 209-221, 2016. http://journal.uny.ac.id/index.php/jpe

[5] Lexy. J. Moleong. Metodologi Penelitian Kualitatif, Bandung: PT Remaja Rosdakarya. 2000

[6] Sugiyono, Metode Penelitian Pendidikan (Pendekatan Kuantitatif, Kualitatif dan R\&D) (1st ed.). Alfabeta CV, 2016

[7] I. Wijayani, E. Y. Haenilah, and Sugiman, "Hubungan Motivasi Belajar Dengan Prestasi Belajar Siswa Kelas V,” Jurnal Pedagogi, vol. 6, no. 6, pp. 3-7, 2017

[8] A. Yudianto, "Penerapan Video Sebagai Media Pembelajaran," Seminar Nasional Pendidikan 2017, pp. 234-237, 2017

[9] Aquami, "Pengaruh Motivasi Belajar Dan Penggunaan Sarana Belajar Terhadap Hasil Belajar Siswa Di Ma Paradigma Palembang”, Istinbath, vol. 15, no, 2 pp. 45-69, 2016

[10] R. Arianti, Indrawati, and I. Wicaksono, "Efektivitas Media Video Animasi Materi Pemanasan Global Terhadap Aktivitas Dan Hasil Belajar Siswa", Pendidikan Fisika, vol. 5 no. 2, 2020

[11] D. A. Rahma, and Arwin, "Pengembangan Media Pembelajaran Video. Animasi Berbasis Sparkol Videoscribe Pada Pembelajaran Tematik Terpadu Di Kelas V Sekolah Dasar," Jurnal Pendidikan Tata

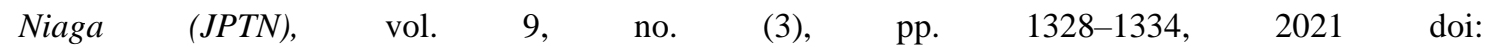
https://jurnalmahasiswa.unesa.ac.id/index.php/jptn/article/view/36419/32383

[12] Agustiningsih, "Video Sebagai Alternatif Media Pembelajaran Dalam Rangka Mendukung Keberhasilan Penerapan Kurikulum 2013 Di Sekolah Dasar,” Pedagogia : Jurnal Pendidikan, vol. 4, no. 1, pp. 50-58. 2015 doi: 10.21070/pedagogia.v4i1.72.

[13] Kartini, K. Sepdyana, and I. N. T. A Putra, "Respon Siswa Terhadap Pengembangan Media Pembelajaran Interaktif Berbasis Android.” Jurnal Pendidikan Kimia Indonesia vol. 4, no. 1, pp. 12, 2020. doi: 10.23887/jpk.v4i1.24981.

[14] Humaidi, A. Qohar, and S. Rahardjo, "Respon Siswa Terhadap Penggunaan Video Youtube Sebagai Media Pembelajaran Daring Matematika.” JIPM (Jurnal Ilmiah Pendidikan Matematika), vol. 10, no. 2, pp. 153. 2021. doi: 10.25273/jipm.v10i2.9108.

[15] Fadhli, and Muhibuddin, "Pengembangan Media Pembelajaran Berbasis Video Kelas Iv Sekolah Dasar." 
Jurnal Dimensi Pendidikan Dan Pembelajaran, vol. 3, no. 1, pp. 24-29, 2015. doi: 10.24269/dpp.v3i1.157.

[16] Williyana, B. A Irma, Y. N. Kholisho, and A. Fathoni, "Pengembangan Media Pembelajaran Berbasis Video Tutorial Interaktif Pada Mata Pelajaran.” EDUMATIC: Jurnal Pendidikan Informatika vol. 2, no. 2, pp. 52, 2018. doi: 10.29408/edumatic.v2i2.869.

[17] Ilsa, Aulya, F. Farida, and M. Harun. "Pengembangan Video Pembelajaran Dengan Menggunakan Aplikasi Powerdirector 18 Di Sekolah Dasar.” Jurnal Basicedu vol. 5, no. 1, pp. 288-300, 2020. doi: 10.31004/basicedu.v5i1.643. 